\title{
PENGARUH KOMPENSASI TERHADAP KINERJA KARYAWAN PADA PERUSAHAAN MODE FURNITURE PEMATANGSIANTAR
}

\author{
Oleh: \\ Linda Syahputra \\ S1 Manajemen \\ Darwin Lie, Parman Tarigan, Efendi
}

\begin{abstract}
Abstraksi
Perusahaan Mode Furniture Pematangsiantar adalah bisnis yang bergerak di bidang produksi dan pemasaran perabotan rumahtangga dan perkantoran. Hasil kerja karyawan dinilai sesuai indikator kinerja yaitu kuantitas hasil, kualitas, ketepatan waktu output, kehadiran dan kerjasama. Salah satu hal yang memicu semangat karyawan dalam bekerja adalah kompensasi yang mereka terima. Adapun pemberian kompensasi oleh Perusahaan Mode Furniture Pematangsiantar yaitu berupa gaji, upah, tunjangan harian dan tunjangan tahunan. Adapun rumusan masalah penelitian ini adalah bagaimana pengaruh kompensasi terhadap kinerja karyawan dan hal-hal yang perlu diperbaiki agar mampu menghasilkan kinerja yang lebih baik melalui pemberian kompensasi yang adil dan layak.

Hasil analisa menunjukkan bahwa pengujian regresi yaitu: $\hat{Y}=15,79+0,65 X$ yang menunjukkan tanda positif, dengan nilai $\mathrm{r}$ sebesar 0,78 yang berarti hubungan kedua variabel adalah kuat. Dari koefisien determinasi dapat dijelaskan tinggi rendahnya kinerja 60,84\% oleh kompensasi dan 39,16\% dijelaskan oleh faktor-faktor lain yang tidak dibahas dalam penelitian ini. Kinerja karyawan harus ditingkatkan untuk itu perusahaan harus memperhatikan kesejahteraan karyawan khususnya dalam hal pemberian kompensasi yang adil dan layak sehingga karyawan dapat memberikan kinerja yang lebih optimal pada Perusahaan Mode Furniture Pematangsiantar.
\end{abstract}

Kata Kunci: Kompensasi dan Kinerja Karyawan.

\section{Abstraction}

Company of Mode of Furniture Pematangsiantar is business which is active in production and marketing of housewares rumahtangga and white colars. Result of employeement job assessed by according to performance indicator that is amount of result of quality, accuracy of time output, attendance and cooperation. One of matter triggering the spirit of employees in working is compensation which they is accepted. As for compensation gift by Company of Mode of Furniture Pematangsiantar that is in the form of salary, fee, daily subsidy and annual subsidy. As for this research problem formula is how compensation influenced to employees performance and is things required to improve repaired so to be able to yield the better performance through competent and fair compensation gift.

Result of analysis indicate that the examination regresion that is $=15.79+0.65 X$ showing positive sign, with the value $r$ of equal to 0.78 meaning second relation of variable is strength. From high explainable coefficient determinasi lower the performance nya $60.84 \%$ by compensation and $39.16 \%$ explained by other factors is which is not discussed in by this research. Employees performance have to be improved for that company have to pay attention to the employees prosperity specially in the case of competent and fair compensation gift so that employees can give the more optimal performance at Company of Mode of Furniture Pematangsiantar

Keyword: Compensation and Employees Performance

\section{A. PENDAHULUAN}

\section{Latar Belakang Masalah}

Keberhasilan perusahaan dalam mencapai tujuannya dipengaruhi oleh beberapa faktor, salah satu yang penting adalah sumber daya manusia. kinerja karyawan dalam kategori sangat rendah, rendah dan sedang harus diupayakan ke kategori tinggi, kinerja kategori tinggi dan sangat tinggi agar dipertahankan demi tercapainya tujuan perusahaan. Kompensasi yang adil dan layak dapat memotivasi karyawan dalam bekerja.

Adapun pemberian kompensasi pada Perusahaan Mode Furniture Pematangsiantar adalah gaji untuk karyawan tetap, upah untuk karyawan harian, tunjangan harian antara lain: uang makan, uang kerajinan, uang ketrampilan, uang transportasi, dan uang lembur, tunjangan kesehatan, Jamsostek, tunjangan hari raya, bonus, fasilitas pakaian dinas, mobil dinas, dapur dan darmawisata setahun sekali untuk karyawan tetap.

\section{Rumusan Masalah}

Berdasarkan uraian dari latar belakang di atas, maka rumusan masalah penelitian ini adalah: 
1. Bagaimana gambaran pemberian kompensasi dan kinerja karyawan pada Perusahaan Mode Furniture Pematangsiantar?

2. Seberapa besar pengaruh pemberian kompensasi terhadap kinerja karyawan pada Perusahaan Mode Furniture Pematangsiantar?

\section{Tujuan Penelitian}

Adapun tujuan penelitian yang dilakukan adalah sebagai berikut:

a. Untuk mengetahui gambaran pemberian kompensasi dan kinerja karyawan pada Perusahaan Mode Furniture Pematangsiantar.

b. Untuk mengetahui besarnya pengaruh pemberian kompensasi terhadap kinerja karyawan pada Perusahaan Mode Furniture Pematangsiantar.

\section{METODE PENELITIAN}

Penelitian ini menggunakan pendekatan penelitian eksplanatoris. Penelitian ini merupakan penelitian populasi, dengan variabel bebas (Kompensasi) dan variabel terikat (Kinerja Karyawan). Teknik pengumpulan data melalui tehnik kuesioner, tehnik wawancara dan dokumentasi. Sumber data dari sumber data primer dan sekunder dengan jenis data kualitatif dan kuantitatif. Selanjutnya data dianalisis dengan metode deskriptip kualitatif dan kuantitatif.

\section{B. LANDASAN TEORI}

\section{Kompensasi}

Menurut

Hasibuan

(2002:118),

"kompensasi adalah semua pendapatan yang berbentuk uang, barang langsung atau tidak langsung yang diterima karyawan sebagai imbalan atas jasa yang diberikan kepada perusahaan". Menurut Wibowo (2011:348), "kompensasi merupakan kontra prestasi terhadap penggunaan tenaga kerja atau jasa yang telah diberikan oleh tenaga kerja atau sebagai imbalan atas penggunaan tenaga kerjanya". Menurut Werther dan Davis dalam Wibowo (2011:348), mendefenisikan "kompensasi sebagai apa yang diterima pekerja sebagai tukaran atas kontribusinya kepada organisasi".

Menurut Hasibuan (2002:121), “tujuan pemberian kompensasi (balas jasa) antara lain adalah ikatan kerja sama, kepuasan kerja, pengadaan efektif, motivasi, stabilitas karyawan, disiplin, serta pengaruh serikat buruh dan pemerintah".

Penjelasannya sebagai berikut :

a. Ikatan Kerja Sama

b. Kepuasan Kerja

c. Pengadaan Efektif

d. Motivasi

e. Stabilitas Karyawan

f. Disiplin

g. Pengaruh Serikat Buruh

h. Pengaruh Pemerintah

Menurut Mathis dan Jackson (2011:419), program kompensasi yang efektif dalam sebuah organisasi memiliki empat tujuan yaitu : a. Kepatuhan pada hukum dan peraturan yang berlaku

b. Efektifitas biaya bagi organisasi

c. Keadilan internal, eksternal dan individual bagi para karyawan

d. Peningkatan kinerja bagi organisasi

Menurut Hasibuan (2002:18), jenis-jenis kompensasi adalah sebagai berikut:

a. Kompensasi Langsung (Direct Compensation)

b. Kompensasi langsung berupa gaji, upah dan insentif, yang merupakan hak bagi karyawan dan menjadi kewajiban perusahaan untuk membayarnya. Gaji adalah balas jasa yang dibayar secara periodik kepada karyawan tetap, sedangkan upah adalah balas jasa yang dibayarkan kepada pekerja harian dengan berpedoman atas perjanjian yang telah disepakati. Insentif adalah tambahan balas jasa yang diberikan kepada karyawan tertentu yang prestasinya diatas prestasi standar.

c. Kompensasi Tidak Langsung (Indirect Compensation)

d. Kompensasi tidak langsung merupakan kompensasi yang diberikan kepada karyawan berupa kesejahteraan karyawan (employee welfare) yang diberikan berdasarkan kebijaksanaan perusahaan terhadap semua karyawan dalam usaha untuk meningkatkan kesejahteraan mereka. Contohnya seperti tunjangan hari raya, uang pensiunan, pakaian dinas, mushola, kafetaria dan darmawisata.

Menurut Wibowo (2011:352), pemberian kompensasi dapat berupa:

a. Upah dan Gaji

b. Insentif

c. Penghargaan

d. Tunjangan

Menurut Mathis dan Jackson (2011:420), ada dua jenis umum komponen nyata dari program kompensasi yaitu:

a. Kompensasi langsung: kompensasi langsung seperti gaji pokok dan penghasilan tidak tetap. Gaji pokok berupa upah dan gaji. Penghasilan tidak tetap berupa bonus, insentif, opsi saham.

b. Kompensasi Tidak Langsung: kompensasi tidak langsung seperti tunjangan karyawan berupa asuransi kesehatan, cuti berbayar, dana pensiun, dan lain-lain.

Menurut Handoko (2011:246), penentuan kompensasi berdasarkan kebijaksanaan dan praktek manajemen oleh interaksi dari tiga faktor yaitu:

a. Kesediaan membayar

b. Kemampuan membayar

c. Persyaratan-persyaratan pembayaran

Menurut Wibowo (2011:352), "sistem pembayaran gaji dan upah bersifat spesifik yaitu team-based pay dan skill-based pay". Team-based pay merupakan kompensasi yang memberikan penghargaan individual atas kerja sama kelompok atau memberi penghargaan tim atas hasil kolektif. Skill-based pay merupakan upah yang dibayar pada tingkat yang diperhitungkan dan berdasarkan 
ketrampilan pekerja menguasai, menunjukkan dan berkembang dalam mewujudkan pekerjaan mereka.

\section{Kinerja}

Umumnya dikatakan bahwa kinerja merupakan sinonim dari kata prestasi kerja (performan) yaitu suatu hasil yang dicapai atas kemampuan untuk melakukan sesuatu menurut standar yang ditetapkan. Berikut pengertian kinerja menurut beberapa ahli:

Menurut Hasibuan (2002:93), "kinerja adalah suatu hasil kerja yang dicapai seseorang dalam melaksanakan tugas-tugas yang dibebankan kepadanya yang didasarkan atas kecakapan, pengalaman, dan kesungguhan, serta waktu". Menurut Mangkunegara (2002:67), "kinerja didefinisikan sebagai hasil kerja secara kualitas dan kuantitas yang dicapai oleh seorang pegawai dalam melaksanakan tugas sesuai tanggungjawab yang diberikan kepadanya". Menurut Sedarmayanti (2007:87), "kinerja diterjemahkan menjadi prestasi kerja, pelaksanaan kerja, hasil kerja atau unjuk kerja”.

Menurut Mathis dan Jackson (2006:378), kinerja karyawan yang umum untuk kebanyakan pekerjaan meliputi elemen sebagai berikut:

a. Kuantitas dari hasil yaitu volume kerja yang dihasilkan.

b. Kualitas dari hasil yaitu kerapian, ketelitian dan keterkaitan hasil dengan tidak mengabaikan volume pekerjaan.

c. Ketepatan waktu dari hasil yaitu penggunaan masa kerja yang disesuaikan dengan kebijaksanaan perusahaan.

d. Kehadiran yaitu kehadiran setiap harinya di tempat kerja.

e. Kemampuan bekerjasama yaitu kemampuan menangani hubungan dalam melakukan pekerjaan.

Menurut Guritno dan Waridin dalam Dito (2010:30), indikator kinerja adalah sebagai berikut:

a. Mampu meningkatkan target pekerjaan

b. Mampu menyelesaikan pekerjaan tepat waktu

c. Mampu menciptakan inovasi dalam menyelesaikan pekerjaan

d. Mampu menciptakan kreatifitas dalam menyelesaikan pekerjaan

e. Mampu meminimalkan kesalahan pekerjaan.

Berdasarkan hal diatas diketahui bahwa

kinerja karyawan dapat dilihat dari segi kualitas dan kuantitas yang dihasilkan, penggunaan jam kerja secara efektif yaitu ketepatan waktu dan kehadiran karyawan, serta kerjasama antar karyawan.

Menurut Gibson, Ivancevich dan Donelly (2000:256), terdapat tiga faktor yang mempengaruhi kinerja: Atribut individu, Kemampuan untuk bekerja, Dukungan organisasi.

Menurut Mathis dan Jackson (2011:113), "faktor utama kinerja individual adalah kemampuan untuk melakukan pekerjaan, tingkat usaha yang dicurahkan dan dukungan organisasi”.

\section{PEMBAHASAN}

\section{Analisa}

\section{a. Analisa Deskriptif Kualitatif}

\section{Pemberian Kompensasi}

Bentuk kompensasi yang diterima karyawan Perusahaan Mode Furniture Pematangsiantar yaitu kompensasi langsung yang berupa gaji, upah dan tunjangan harian, sedangkan kompensasi tidak langsung yang berupa tunjangan tahunan dan fasilitas kerja lainnya.

\section{a) Pemberian kompensasi langsung}

Kompensasi langsung ini diberikan oleh perusahaan dalam bentuk gaji, upah dan tunjangan harian yang prosesnya berjalan berulang-ulang setiap bulan. Gaji yang diterima karyawan tetap adalah berdasarkan kesepakatan bersama, jika ditambah dengan tunjangan makan maka totalnya diperhitungkan $\pm \mathrm{Rp}$ 1.200.000,- sampai 2.650.000,. Upah karyawan harian yaitu upah pokok dikali dengan jumlah kehadiran ditambah dengan tunjangan lembur (jika ada), tunjangan kerajinan dan tunjangan lainnya maka total upah yang diterima \pm Rp 800.000,- sampai Rp 1.400.000,-. Sedangkan untuk karyawan borongan walaupun tidak ada perjanjian kontrak namun tetap diberikan borongan kerja yang cukup menjanjikan setiap bulannya. Untuk upah borongan yang diterima adalah sesuai kesepakatan harga per-unit yaitu $\pm \mathrm{Rp} 200.000$,sampai Rp 1.000.000,- tergantung pada tingkat kesulitan pengerjaan permintaan barang tersebut. Diperkirakan setiap borongan kerja adalah minimal 10 unit setiap bulannya maka total upah borongan yang diterima adalah $\pm \mathrm{Rp} 2.000 .000$,- sampai $\mathrm{Rp}$ 10.000.000,-.

Tunjangan makan/uang makan diberikan perusahaan kepada karyawan tetap sebesar Rp 6.000,- setiap hari kerja, uang makan dengan jumlah yang sama juga diberikan kepada karyawan harian apabila mereka bekerja pada saat jam makan. Tunjangan Transportasi/uang transportasi diberikan kepada karyawan harian sebesar Rp 6.000,- per hari, sedangkan untuk karyawan tetap diberikan fasilitas antar jemput dengan menggunakan mobil dinas. Tunjangan lembur/uang lembur hanya diberikan kepada karyawan harian apabila mereka melakukan pekerjaan melebihi jam kerja yang telah disepakati. Besarnya uang lembur adalah Rp 2.000,- per jam dengan kesepakatan jam kerja karyawan produksi/karyawan di pabrik \pm 7,5 jam setiap hari, sedangkan untuk karyawan tetap di toko dengan jam kerja \pm 9 jam setiap hari, tanpa mendapatkan uang lembur.

Tunjangan kerajinan juga hanya diberikan kepada karyawan harian dengan syarat absen yang tidak melebihi dua hari setiap bulan maka jika karyawan tidak dapat memenuhi syarat tersebut, tunjangan kerajinannya akan hangus. Besarnya uang kerajinan adalah Rp 2.000,- per hari. Begitu pula dengan tunjangan ketrampilan yang hanya diberikan kepada karyawan harian, besarnya untuk setiap karyawan berbeda-beda sebab tingkat ketrampilan setiap karyawan juga berbeda-beda yaitu \pm Rp 1.000 sampai Rp 8.000,- setiap hari. Tunjangan prestasi 
juga diterima oleh karyawan harian saja, besarnya berbeda-beda disesuaikan dengan kinerja mereka yaitu \pm Rp 1.000 sampai Rp 5.000,- setiap hari.

\section{b) Pemberian kompensasi Tidak langsung}

Kompensasi tidak langsung diberikan oleh perusahaan dalam bentuk tunjangan yaitu tunjangan kesehatan yang berupa berobat gratis dan program Jamsostek, tunjangan tahunan yang berupa tunjangan hari raya dan bonus, dan fasilitas lain yang berupa pakaian dinas, mobil dinas, dapur, dan darmawisata. Tunjangan kesehatan yang berupa Jamsostek merupakan program wajib yang memberikan hak masyarakat terutama pekerja dan pengusaha terhadap perlindungan resiko hilangnya penghasilan dan biaya perawatan medis. Sedangkan darmawisata merupakan program yang diadakan perusahaan setahun sekali guna menghilangkan kepenatan karyawan terhadap kesibukan kerja sehingga diharapkan dapat menumbuhkan semangat kerja karyawan kembali.

Tunjangan kesehatan yang diberikan yaitu berupa jaminan kesehatan kepada seluruh karyawan. Apabila karyawan mengalami sakit ringan, karyawan dapat memeriksakan diri secara gratis pada klinik/tempat praktek milik pimpinan perusahaan sendiri, bahkan untuk keluarga dekat diberikan keringanan biaya. Sedangkan untuk program Jamsostek tidak semua karyawan mendapatkannya sebab pimpinan mempertimbangkan berdasarkan jenis pekerjaan yang lebih beresiko dan berdasarkan kesetiaan/lama bekerja karyawan sebab mayoritas karyawan adalah karyawan harian yang tidak dapat dipastikan/diperkirakan akan bertahan bekerja sampai kapan.

Tunjangan hari raya merupakan tunjangan tahunan yang diberikan setiap tahun yaitu sejumlah 1 bulan upah atau gaji pokok, sedangkan untuk karyawan borongan adalah $\pm \mathrm{Rp} 1.000 .000$ sampai Rp 1.500.000,-. Bagi karyawan harian, sistem penerimaan THR dibagi menjadi dua kali yaitu THR I ( 2 minggu sebelum lebaran) dan THR II (akhir bulan bersama dengan penerimaan upah). Bonus juga diberikan setiap tahun kepada karyawan harian sebagai hadiah atas loyalitas mereka terhadap perusahaan. Bonus biasanya berupa materi pakaian.

\section{Kinerja Karyawan}

Faktor yang mempengaruhi kinerja karyawan pada Perusahaan Mode Furniture Pematangsiantar adalah faktor individu yang menghasilkan kinerja itu sendiri, yaitu kemampuan karyawan dalam melaksanakan instruksi pekerjaan, tanggungjawab, pengalaman kerja yang diterapkan, disiplin/pemanfaatan waktu bekerja secara maksimal. Sedangkan faktor lingkungan perusahaan yang turut mendukung kinerja karyawan adalah hubungan kerja yang harmonis seperti terciptanya kerjasama antar karyawan, iklim kerja yang respek dan dinamis serta fasilitas kerja yang memadai. Perbedaan kinerja antar karyawan juga dipengaruhi faktor umur, jenis kelamin, kepribadian dan sebagainya.
Pada indikator kuantitas kerja berada pada kriteria sangat tinggi dan indikator ketepatan waktu output berada pada kriteria tinggi. Indikator kualitas pekerjaan yaitu ketrampilan dan kreatifitas yang maksimal. Indikator ketepatan waktu berproduksi Indikator kehadiran termasuk kriteria sangat tinggi. Dalam indikator sikap kerjasama, tercapainya kerjasama yang baik antar para karyawan.

\section{c. Analisa Deskriptif Kuantitatif \\ 1. Regresi Linier Sederhana}

Untuk melihat pengaruh variabel dengan persamaan regresi tersebut maka dilakukan perhitungan secara manual untuk memperoleh nilai a dan $b$, dengan rumus persamaan: $\ddot{Y}=a+b X$. Berdasarkan hasil pengolahan data didapat persamaan regresi linier sederhana sebagai berikut: $\hat{\mathrm{Y}}=15,79+0,65 \mathrm{X}$ dimana persamaan regresi bertanda positif, yaitu terdapat pengaruh positif antara variabel bebas (kompensasi) terhadap variabel terikat (kinerja) pada Perusahaan Mode Furniture Pematangsiantar, artinya semakin baik pemberian kompensasi maka semakin tinggi pula kinerja karyawan.

\section{Korelasi dan Determinasi}

Selanjutnya dilakukan perhitungan korelasi berupa derajat atau kedalaman hubungan fungsional yang menjelaskan hubungan antar peubah/variabel, dinyatakan dengan yang dinamakan koefisien korelasi yang sering disimbolkan dengan r. Dari perhitungan diperoleh nilai $r=0,78$. Hal ini menunjukkan adanya hubungan yang kuat antara variabel $\mathrm{X}$ yaitu kompensasi terhadap variabel $\mathrm{Y}$ yaitu kinerja.

Untuk mengetahui berapa besar kontribusi kompensasi dapat mempengaruhi tingkat kinerja karyawan, maka perlu dilakukan perhitungan melalui koefisien determinasi/penentu (KD) dan diperoleh nilai KD 60,84\%, menunjukkan bahwa tinggi rendahnya kinerja karyawan pada Perusahaan Mode Furniture Pematangsiantar sebesar 60,84\% dapat dijelaskan oleh kompensasi, sedangkan sisanya $39,16 \%$ dijelaskan oleh faktor-faktor lain yang tidak dibahas dalam penelitian ini seperti: kepemimpinan, motivasi, komunikasi, dan sebagainya.

\section{Uji Hipotesis (uji t)}

Untuk menguji penelitian ini apakah signifikan atau tidak signifikan hubungan antara kedua variabel adalah dengan uji statistik koefisien korelasi yaitu uji t sehingga dapat ditentukan kriteria penerimaan atau penolakan penelitian.

Dengan kriteria pengujian, Jika $t_{\text {hit }}$ lebih dari $\mathrm{t}_{\mathrm{tab}}$ dengan tingkat kekeliruan 5\% $(\alpha=0,05)$ derajat bebas $(\mathrm{dk})=\mathrm{n}-2$, maka dinyatakan signifikan dan demikian juga jika $t_{\text {tab }}(\alpha=0,05)$ besar dari $t_{\text {hit }}$ maka dinyatakan tidak signifikan/berarti penelitian yang diajukan ditolak.

Dari hasil perhitungan diperoleh nilai $t_{\text {hit }}>$ $t_{\text {tab }}(6,83>2,042)$ berarti variabel kompensasi 
berpengaruh terhadap kinerja karyawan, sehingga Ho ditolak dan Ha diterima, artinya kompensasi berpengaruh positif terhadap kinerja karyawan pada Perusahaan Mode Furniture Pematangsiantar.

\section{Evaluasi}

\section{a. Kompensasi}

Dari rekapitulasi jawaban responden mengenai pemberian kompensasi pada Perusahaan Mode Furniture Pematangsiantar dapat dilihat bahwa nilai rata-rata yang lebih rendah dibanding yang lain adalah hal pemberian tunjangan harian. Pimpinan harus lebih bijaksana dalam menetapkan tunjangan harian para karyawan sebab sebagian karyawan menjawab rendah bahkan ada yang menjawab sangat rendah untuk pemberian tunjangan harian karena mereka merasa pembagian kurang memadai khususnya dalam pemberian uang lembur yang masih kurang terealisasi dimana karyawan telah bekerja melebihi standart jam kerja yang menurut UU pasal 77 ayat 1 No.13/2003 yaitu jam kerja karyawan yang bekerja 6 hari dalam seminggu adalah 7 jam kerja per hari.

Nilai rata-rata yang lebih rendah lainnya mengenai pemberian kompensasi adalah hal pemberian tunjangan kesehatan. Pimpinan perusahaan perlu memperhatikan pemberian kompensasi tidak langsung yaitu tunjangan kesehatan yang berupa Jamsostek yang selama ini hanya diberikan pada beberapa karyawan tertentu. Pembagian ini dirasa tidak adil walaupun setiap karyawan mendapatkan kesempatan berobat gratis di klinik milik pimpinan perusahaan sendiri namun dengan adanya program Jamsostek dapat memberi jaminan hari tua karyawan yang mendapatkannya, karena itu karyawan memberi nilai rendah sebab pembagian tunjangan kesehatan dalam bentuk Jamsostek ini dirasakan tidak sesuai/tidak adil.

Mengenai pemberian gaji yang sudah sesuai dengan peraturan pemerintah karena telah memenuhi UMP yang berlaku, mayoritas karyawan menjawab tinggi. Tanggapan karyawan terhadap kompensasi upah yang sudah sesuai dengan pemenuhan kebutuhan hidup juga tinggi namun ada beberapa karyawan yang merasa cukup tinggi karena karyawan sebagai manusia yang umumnya memiliki sifat tidak pernah merasa puas dengan hal yang berkaitan dengan hak-hak mereka.

Pemberian kompensasi juga harus disesuaikan dengan apa yang menjadi beban tanggungjawab karyawan. Untuk hal ini karyawan menjawab tinggi karena karyawan beranggapan bahwa apa yang mereka terima telah sesuai dengan beban kerja mereka. Pemberian kompensasi sudah sesuai dengan pendidikan yang dimiliki karyawan juga ditanggapi sebagian besar karyawan dengan jawaban sangat tinggi, maka dapat diambil kesimpulan bahwa mereka sangat setuju. Ketepatan waktu dalam pemberian kompensasi juga dinilai sangat tinggi karena karyawan tidak pernah mengalami keterlambatan pembayaran atas hak-hak mereka, hal ini tentu saja dapat menjadi salah satu faktor karyawan untuk merasa nyaman bekerja di perusahaan.

Tunjangan tahunan seperti tunjangan hari raya yang sesuai dan bonus yang bernilai guna telah diberikan dengan baik, ini terlihat dari mayoritas karyawan menjawab tinggi atau berarti setuju atas hal tersebut. Selanjutnya tanggapan yang tinggi juga diberikan atas fasilitas kerja yang sudah memadai dan bernilai guna bagi karyawan.

Pemberian kompensasi yang kurang adil kepada para karyawan akan memicu kecemburuan sehingga dapat terjadi perpecahan antar karyawan. Perusahaan harus benar-benar memperhatikan pemberian kompensasi yang adil dan layak sebab kompensasi yang memadai dapat menjadi kepuasan kerja bagi karyawan, yang akan membantu perusahaan untuk memperoleh, memelihara, mempertahankan tenaga kerja yang produktif dan memicu kinerja yang lebih tinggi sehingga proses pencapaian tujuan perusahaan dapat berjalan lancar.

\section{b. Kinerja Karyawan}

Dari rekapitulasi jawaban responden mengenai kinerja pada Perusahaan Mode Furniture Pematangsiantar dapat dilihat bahwa nilai rata-rata yang lebih rendah dibanding yang lain adalah hal menghasilkan produk sesuai jadwal yang diberikan. Produksi yang tidak selesai sesuai jadwal dapat disebabkan karena mengalami beberapa kendala diantaranya kemampuan karyawan yang terbatas atau juga bisa dikarenakan cuaca yang kurang mendukung. Dalam hal ini pimpinan perusahaan dapat mengadakan pelatihan untuk meningkatkan kualitas kerja karyawan. Pimpinan perusahaan juga dapat menyediakan ruangan dengan mesin steam khusus untuk pengeringan perabotan sehingga perusahaan tidak lagi perlu mengkhawatirkan faktor cuaca buruk yang memperlambat proses produksi, bahkan dengan ruangan khusus tersebut pimpinan perusahaan dapat mengurangi resiko rusaknya bahan baku kayu akibat binatang rayap.

Nilai rata-rata yang lebih rendah lainnya mengenai kinerja adalah hal sanksi atas ketidakhadiran karyawan yang dirasa setimpal. Pimpinan perusahaan juga perlu memperhatikan pemberian sanksi atas ketidakhadiran karyawan khususnya kepada para karyawan harian agar karyawan tidak mengalami kekecewaan yang akhirnya menyebabkan karyawan akhirnya resign dari perusahaan. Dengan memberikan kelonggaran terhadap perhitungan pengurangan upah atas ketidakhadiran dan mensosialisasikan beberapa butir dari alasan ketidakhadiran yang kuat/dapat dibuktikan kebenarannya dan dapat dimaklumi, maka karyawan tidak akan merasa tertekan atas sanksi yang mereka terima.

Dalam indikator kuantitas kerja, karyawan menilai sangat tinggi untuk produksi yang dapat berjalan lancar sehingga karyawan dapat mencapai target yang ditetapkan. Sama halnya dengan target produksi, karyawan juga menilai sangat tinggi untuk hasil penjualan yang tercapai sesuai yang diharapkan. Walaupun kedua indikator kuantitas ini 
berada dalam kondisi sangat baik, perusahaan harus tetap memperhatikan beberapa hambatan penjualan karena penjualan tidak selalu stabil yang dipengaruhi kemampuan karyawan dalam membujuk konsumen maupun faktor luar seperti kemampuan membeli konsumen itu sendiri. Untuk meningkatkan target penjualan, perusahaan dapat mengambil kebijakan dengan memberi pelatihan komunikasi untuk karyawan atau perusahaan juga dapat memberi keringanan dan kemudahan kredit sehingga dapat membantu kesulitan ekonomi konsumen yang ingin membeli namun kurang mampu.

Untuk indikator kualitas kerja, sebagian karyawan menilai tinggi atau setuju bahwa ketrampilan dan kreativitas yang karyawan berikan sudah maksimal, minoritas yang menilai cukup tinggi disebabkan kemampuan dan pengalaman kerja setiap karyawan yang berbeda. Dalam hal ini perusahaan dapat memberi pelatihan dan pengembangan sesuai jenis pekerjaan karyawan masing-masing. Adanya keluhan dari pihak konsumen juga kiranya ditanggapi baik dan cepat oleh para karyawan sehingga tingkat keluhan yang terjadi semakin berkurang. Selanjutnya hal ketepatan waktu bagi mayoritas karyawan melaksanakan pekerjaan tepat waktu adalah komitmen kerja. Karyawan menilai tinggi untuk produksi yang dapat berjalan lancar sesuai jadwal yang ditetapkan, namun ada beberapa yang menilai cukup tinggi dikarenakan perbedaan kemampuan dan juga faktor cuaca. Keseimbangan antara deadline produksi dengan kemampuan dan situasi kerja adalah sangat penting, sebagian besar karyawan menilai tinggi untuk kesesuaian jangka waktu yang diberikan dalam memenuhi permintaan produksi. Jika karyawan bekerja secara buru-buru maka hal tersebut akan sangat mempengaruhi kualitas produk itu sendiri.

Dalam hal kehadiran, karyawan semua dapat hadir tepat waktu. Sebagian karyawan menjawab tinggi/setuju terhadap pernyataan bahwa sanksi yang diberikan apabila terjadi absensi adalah sesuai dan setimpal, dimana pimpinan hanya akan menegur karyawan yang terlalu sering tidak hadir tanpa alasan yang tepat dan apabila karyawan tetap tidak menghiraukan teguran dari pimpinan dan terus menerus melakukan absen maka karyawan akan kehilangan pekerjaan mereka. Namun beberapa karyawan yang lain merasa hal tersebut cukup merugikan sebab untuk karyawan harian ketidakhadiran dengan atau tanpa alasan tepat akan tetap sangat mempengaruhi penghitungan upah yang akan mereka terima.

Indikator sikap kerjasama menunjukkan usaha dan loyalitas sebagai karyawan sehingga tercipta kerjasama yang baik. Pelaksanaan tugas dan tanggungjawab sesuai dengan ketentuan perusahaan juga menunjukkan adanya kerja keras dan pengabdian karyawan dalam melaksanakan tugas sesuai instruksi dari atasan. Beberapa karyawan merasa cukup setuju karena beberapa hal instruksi pekerjaan dari atasan dinilai tidak sesuai dengan situasi/kondisi yang terjadi.

Dengan adanya berbagai atribut yang melekat pada individu akan membedakan karyawan yang satu dengan karyawan yang lain, seperti perbedaan jenis kelamin, umur, pendidikan, pengalaman, dan kemampuan dalam bekerja. Hal ini dapat menjadi hambatan maupun dukungan untuk mendapatkan kinerja yang maksimal dari karyawan. Usaha dan kemauan keras dari individu serta dukungan dari perusahaan juga sangat menentukan hasil kerja yang dicapai. Salah satu dukungan perusahaan adalah hal pemberian kompensasi, oleh karena itu pimpinan Perusahaan Mode Furniture Pematangsiantar dalam hal meningkatkan kinerja karyawannya dapat berusaha memberikan yang terbaik kepada karyawan yaitu kompensasi yang sesuai agar karyawan termotivasi untuk meningkatkan kinerja mereka.

\section{KESIMPULAN DAN SARAN}

\section{Kesimpulan}

a. Kompensasi berpengaruh terhadap kinerja karyawan pada Perusahaan Mode Furniture Pematangsiantar, hal ini dapat dilihat dari hasil pengujian regresi yang menunjukkan tanda positif pada persamaan: $\hat{\mathrm{Y}}=15,79+0,65 \mathrm{X}$,

b. Nilai korelasi yang diperoleh: $r=0,78$, menunjukkan adanya hubungan kuat antara kompensasi terhadap kinerja dan tinggi rendahnya kinerja 60,84\% dapat dijelaskan oleh kompensasi dan 39,16\% dijelaskan oleh faktorfaktor lain yang tidak dibahas dalam penelitian ini seperti kepemimpinan, motivasi, komunikasi, dan sebagainya.

c. Pengujian hipotesis menolak Ho dan menerima Ha, karena nilai $t_{\text {hit }}>t_{\text {tab }}$.

\section{Saran}

a. Pimpinan memberi kebijakan yang lebih baik dan melaksanakan perbaikan yang adil merata bagi para karyawan dalam pemberian kompensasi khususnya hal tunjangan uang lembur dan Jamsostek

b. Pimpinan dapat lebih sering menjalin komunikasi yang baik dan membimbing karyawan dalam bekerja sehingga pimpinan dapat mengerti keluhan dan masalah yang karyawan hadapi.

c. Pimpinan mengadakan program pelatihan dan pengembangan untuk memberikan kesempatan bagi karyawan dalam meningkatkan kemampuan mereka.

\section{E. DAFTAR PUSTAKA}

Arikunto, Suharsimi, Prosedur Penelitian Suatu Pendekatan Praktik, Penerbit Rineka Cipta, Jakarta, 2006 
Gibson, James. L., John. M. Ivancevich and James. H. Donelly. Jr., Perilaku Organisasi, Penerbit Erlangga, Bandung, 2000.

Griffin, Ricky W., Manajemen, Jilid Kedua, Penerbit Erlangga, Jakarta, 2004.

Handoko, T. Hani, Manajemen, Edisi Kedua, Cetakan Keduapuluhsatu, Penerbit BPFE, Yogyakarta, 2011.

Hasibuan, Malayu S.P., Manajemen Sumber Daya Manusia, Edisi Revisi, Cetakan Kelima, Penerbit Bumi Aksara, Jakarta, 2002.

Kaswan, Manajemen Sumber Daya Manusia Untuk Keunggulan Bersaing Organisasi, Edisi Pertama, Cetakan Pertama, Penerbit Graha Ilmu, Yogyakarta, 2012.

Mangkunegara, A. A. Anwar Prabu, Manajemen Sumber Daya Manusia Perusahaan, Penerbit Bumi Aksara, Jakarta, 2002.

Mathis, Robert L., John H. Jackson, Manajemen Sumber Daya Manusia, Buku Kedua, Penerbit Salemba Empat, Jakarta, 2006
Human Resources Management, Edisi Kesepuluh, Terjemahan Diana Angelica, Penerbit Salemba Empat, Jakarta, 2011.

Rivai, Veithzal, Manajemen Sumber Daya Manusia Untuk Perusahaan, Penerbit Raja Grafindo Persada, Jakarta, 2006.

Sedarmayanti, Manajemen Sumber Daya Manusia, Reformasi Birokrasi, Dan Manajemen Pegawai Negeri Sipil, Penerbit Refika Aditama, Jakarta, 2007.

Simamora, Henry, Manajemen Sumber Daya Manusia, Edisi Kedua, STIE YKPN, Yogyakarta, 2001.

Sugiyono, Prof., Dr., Metode Penelitian Kuantitatif, Kualitatif dan R \& D, Cetakan Kesebelas, Penerbit Alfabeta, Bandung, 2010.

Undang-undang Ketenagakerjaan, Edisi 2011, Penerbit Fokusmedia, Bandung, 2011.

Wibowo, Manajemen Kinerja, Edisi Ketiga, Cetakan Kelima, Penerbit Rajawali Pers., Jakarta, 2011. 